\title{
Tacrolimus as Antifungal Agent
}

\section{Lyudmyla Antypenko, ${ }^{\star}$ Zhanar Sadykova, Fatuma Meyer, Leif-Alexander Garbe and Karl Steffens}

\author{
Department of Agriculture and Food Science, Neubrandenburg University Brodaer Str. 2, 17033, Neubrandenburg, Germany \\ *Corresponding author: E-mail: antypenkol@gmail.com
}

Received: 09-18-2018

\begin{abstract}
Tacrolimus (FK506) is an immunosuppressant drug widely used to avoid organ rejection in transplant patients. It has a profound influence on the cellular stress response by interfering with the calmodulin-calcineurin signaling pathway. In this context FK506 also became a valuable antifungal drug in medical care. Here it is shown in vitro that tacrolimus has a potent growth inhibition activity against 11 fungi and 3 oomycetes of agricultural importance. The significance of this finding is discussed with respect to crop protection. The in silico molecular docking to 6 major antifungal enzymes determined UDP- $N$-acetylmuramoyl- $L$-alanine: $D$-glutamate ligase (MurD) as the main target by the best affinity score.
\end{abstract}

Keywords: Tacrolimus, Antiphytofungal activity

\section{Introduction}

Presently azoles, echinocandines, pyrimidine analogs and polyenes are among the most common antifungals in human medical care and crop protection. The search for new potent antifungal agents will remain an urgent task at the background of an ongoing emergence of drug resistance. ${ }^{1}$ Especially resistant pathogenic fungi rise concerns human medical care. For instance, immunocompromised patients after HIV infection or organ transplantation, who have overcome cryptococcal meningitis infection, may need a life-time fluconazole prophylaxis. ${ }^{2}$ Here, management of infections become extremely difficult if azole resistant pathogens get involved. Also the arise of fluconazole-resistant mutants among Cryptococcus neoformans clinical isolates was observed. ${ }^{3}$ In search for new targets for antifungals the calmodulin-calcineurin signaling cascade came into focus. A stress response of a fungal cell starts by the uptake of $\mathrm{Ca}^{2+}$, which then binds to the four binding sites of calmodulin. After a conformational change $\mathrm{Ca}^{2+}$ occupied calmodulin forms a ternary complex together with calcineurin subunits $\mathrm{CnA}$ and $\mathrm{CnB}$, thereby gaining a phosphatase activity; in turn the complex dephosphorylates transcription factor Crz1. Genes activated by dephosphorylized Crzl are involved in drug resistance, growth and cell wall integrity. Generally, calcineurin is an important part of the stress response of fungal cells. ${ }^{4}$

Searching for novel immunosuppressive agents a 822-kD 23-membered macrolide lactone named tacrolim-

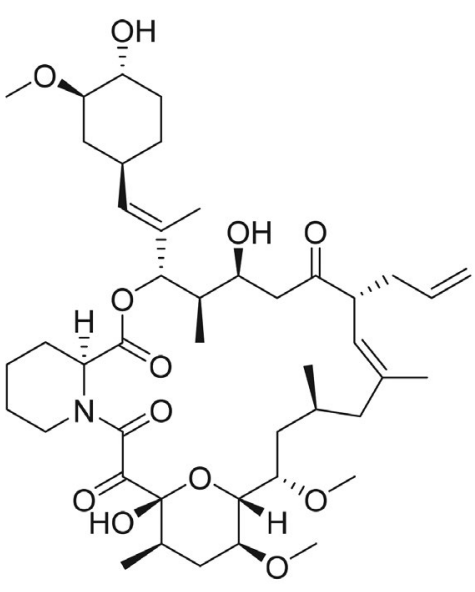

Figure 1. Chemical structure of tacrolimus (FK506).

us (FK506, Fujimycin, etc.) was isolated and characterized from Streptomyces tsukubaensis (Fig. 1). ${ }^{5}$

Tacrolimus in capsules for oral intake and as solution for injection is used for prophylaxis against organ rejection in patients receiving liver, kidney or heart transplants. ${ }^{6}$ As a topical ointment it is applied as a second-line therapy for the short-term and non-continuous chronic treatment of moderate to severe atopic dermatitis in non-immunocompromised adults and children. FK506 has a favorable toxicological profile: no evidence of mutagenicity was observed in vitro in the $\mathrm{CHO} / \mathrm{HGPRT}$ assay (the Chinese hamster ovary cell assay). Also it did not cause unsched- 
uled DNA synthesis in rodent hepatocytes. $\mathrm{LD}_{50}$ in rat oral test was $134 \mathrm{mg} / \mathrm{kg}$ for tacrolimus hydrate. ${ }^{7}$

Experimental evidence suggests that tacrolimus binds to the intracellular protein FKBP12 and thereby interferes with the calcineurin signal pathway, which is a key element in regulation of intracellular $\mathrm{Ca}^{2+}$ concentration. ${ }^{4}$ FKBP12-tacrolimus inhibits the phosphatase activity of the calmodulin-CnA-CnB complex, which in turn silences transcription factor Crzl and corresponding stress related genes. As a consequence, inhibitors of calcineurin like tacrolimus may function as potent antifungals. In combination with standard antifungal drugs FK506 may reverse resistance against them or increase their efficacy. ${ }^{8,9}$ Also phytopathogenic fungi rely on the calcineurin pathway securing cell wall and membrane integrity, virulence ${ }^{10}$ or formation of infectious appressoria. ${ }^{11}$

Practically all of tacrolimus studies are related to the development of supportive antifungal therapy to improve regimes of infected patients. Here we describe novel antifungal efficacy of FK506 towards eleven pathogenic fungi and three Phytophthora oomycetes of agricultural importance.

\section{Results and Discussion}

\section{1. Known Antifungal Data}

All reported antifungal literature data were summarized below (Table 1) to show its found minimum inhibitory concentrations (MIC).

Table 1. Summary of reported antifungal activity of tacrolimus (FK506)

\begin{tabular}{|c|c|c|}
\hline Fungus & Reported strain name & $\mathrm{MIC}_{100}, \mu \mathrm{g} / \mathrm{mL}$ \\
\hline \multirow{6}{*}{ Aspergillus fumigatus } & AF293, DUMC 119.00, & $1.56^{12}$ \\
\hline & DUMC 153.90, DUMC 101.01 & 1.56 \\
\hline & DUMC 165.86 & 6.25 \\
\hline & DUMC 182.99 & 0.39 \\
\hline & DUMC 168.95 & 3.125 \\
\hline & DUMC 131.00 & 0.78 \\
\hline \multirow{3}{*}{ Aspergillus fumigantus } & 6 strains & $0.025-0.4^{13}$ \\
\hline & AF1 - AF10 & $>256^{14}$ \\
\hline & TIMM0063 & $\leq 0.008^{15}$ \\
\hline \multirow{2}{*}{ Aspergillus niger } & 2 strains & $0.006-0.012^{13}$ \\
\hline & ATCC6275 & $\leq 0.008^{15}$ \\
\hline \multirow{2}{*}{ Aspergillus flavus } & 4 strains & $0.1-0.2^{13}$ \\
\hline & AFL1 - AFL8 & $>256^{14}$ \\
\hline \multirow{2}{*}{ Aspergillus terreus } & 4 strains & $0.025-0.1^{13}$ \\
\hline & AT1, AT2 & $>256^{14}$ \\
\hline Aspergillus ustus & 3 strains & $>0.4^{14}$ \\
\hline Aspergillus versicolor & 1 strain & $>0.4^{14}$ \\
\hline \multirow{11}{*}{ Candida albicans } & SC5314, echinocandin-res.: & \\
\hline & Fks1 S645Y, Fks1 F641S, & \\
\hline & Fks1 S645F, Fks1 S645P; & $>16^{16}$ \\
\hline & azole-res.: 2-76, & \\
\hline & $2-86,12-99$ & \\
\hline & $\begin{array}{l}\text { SC5314, cnb1/cnb1 (DAY364), } \\
\text { cnb1/cnb1 CNB1 (MCC85), }\end{array}$ & $>3.12^{1}$ \\
\hline & $\begin{array}{c}\text { CNB1-1/CNB1 (YAG237) } \\
\text { rbp1/rbp1 (YAG171) }\end{array}$ & \\
\hline & azole-susc. CA5, CA8, CA12, & \\
\hline & CA14, CA129; azole-res. CA10, & $512^{18}$ \\
\hline & CA15, CA16, CA135, CA137. & \\
\hline & TIMM1623 & \multirow{3}{*}{$>128^{15}$} \\
\hline Candida tropicalis & TIMM0313 & \\
\hline Candida kefyr & ATCC28838 & \\
\hline
\end{tabular}




\begin{tabular}{|c|c|c|}
\hline Fungus & Reported strain name & $\mathrm{MIC}_{100}, \mu \mathrm{g} / \mathrm{mL}$ \\
\hline Candida glabrata ${ }^{a}$ & $\begin{array}{c}\text { CG1, CG9 } \\
\text { CG4, CG8, CG2, CG3 }\end{array}$ & $\begin{array}{c}256^{19} \\
512\end{array}$ \\
\hline Cryptococcus neoformans & $\begin{array}{c}\mathrm{EP} 1551 \\
8003 \\
\mathrm{H} 99 \\
\mathrm{C} 20, \mathrm{C} 21 \\
\mathrm{C} 20 \mathrm{~F} 1 \\
\mathrm{C} 20 \mathrm{~F} 2, \mathrm{C} 21 \mathrm{~F} 2 \\
\mathrm{C} 21 \mathrm{~F} 3 \\
\Delta c n a 1 \text { mutant, } \Delta \text { frr } 1 \text { mutant }\end{array}$ & $\begin{array}{c}1^{15} \\
2^{15} \\
<0.09^{21} ; 12.5^{20} \\
<0.09^{21} \\
100^{21} \\
50^{21} \\
25^{21} \\
>25^{20}\end{array}$ \\
\hline Cunninghamella spp. ${ }^{b}$ & 2 strains & $0.05-0.2^{13}$ \\
\hline Fusarium spp. ${ }^{\mathrm{b}}$ & 6 strains & $>0.4^{13}$ \\
\hline Lichtheimia spp. ${ }^{\mathrm{b}}$ & 2 strains & $0.2-0.4^{13}$ \\
\hline Malassezia furfur & $\begin{array}{l}8 \text { strains } \\
26 \text { strains }\end{array}$ & $\begin{array}{c}0.03^{22} \\
0.5-32^{15}\end{array}$ \\
\hline Malassezia globose & 36 strains & \multirow[t]{2}{*}{$0.016-0.25^{22}$} \\
\hline Malassezia restrica & 28 strains & \\
\hline Malassezia sympodialis & 19 strains & $0.125^{22}$ \\
\hline Malassezia obtuse & 7 strains & \multirow{2}{*}{$0.03^{22}$} \\
\hline Malassezia slooffiae & 10 strains & \\
\hline Malassezia dermatis & 3 strains & \multirow{2}{*}{$0.016^{22}$} \\
\hline Malassezia japonica & 2 strains & \\
\hline Malassezia nana & 4 strains & \\
\hline Malassezia pachydermatis & 6 strains & \\
\hline Malassezia yamatoensis & 2 strains & \\
\hline Mucor spp. ${ }^{b}$ & 4 strains & 0.012 to $>0.4^{13}$ \\
\hline Paecilomyces licasinus ${ }^{b}$ & 5 strains & $>0.4^{13}$ \\
\hline Paecilomyces varioti ${ }^{b}$ & 4 strains & 0.025 to $>0.4^{13}$ \\
\hline $\begin{array}{l}\text { Rhizomucor spp. } \\
\text { Rhizopus spp. } \\
\end{array}$ & $\begin{array}{l}2 \text { strains } \\
5 \text { strains }\end{array}$ & $\begin{array}{c}0.012-0.025^{13} \\
0.1 \text { to }>0.4^{13} \\
\end{array}$ \\
\hline Scedosporium apiospermum ${ }^{b}$ & 4 strains & 0.05 to $>0.4^{13}$ \\
\hline Scedosporium prolificans ${ }^{b}$ & 4 strains & $>0.4^{13}$ \\
\hline Scopulariopsis spp. ${ }^{b}$ & 4 strains & 0.05 to $>0.4^{13}$ \\
\hline Saccharomyces cerevisiae $e^{b}$ & $\begin{array}{c}\text { YFK005 wild type } \\
\text { YFK007 wild type } \\
\text { YFK012 (fkr1), YFK256 (PDR) } \\
\text { YFK257 (pdrl-3), YFK259 (pdrl-7) } \\
\text { YFK014 (fkr2), YFK258 (PDR) } \\
\text { YFK093 (fkr3) } \\
\text { YFK223-5C (pdrl-3) } \\
\text { YFK222-2A (pdrl-7) }\end{array}$ & $\begin{array}{c}15^{23} \\
22 \\
>80 \\
>80 \\
45 \\
50 \\
6 \\
35\end{array}$ \\
\hline Sporonthrix brasilliensis & CBS 133021 & $1^{24}$ \\
\hline Sporonthrix schenckii & CBS 132984 & $2^{24}$ \\
\hline Trichosporon asahii & CBS 2479 & $>64^{25}$ \\
\hline
\end{tabular}




\begin{tabular}{lcc}
\hline Fungus & Reported strain name & MIC $_{\mathbf{1 0 0}}, \boldsymbol{\mu g} / \mathbf{m L}$ \\
\hline & VUT-77011 & $>100^{26}$ \\
& VUT-97010 & $0.781^{26}$ \\
Trichophyton mentagrophytes & VUT-00001 & $6.25^{26}$ \\
& VUT-00002 & $25^{26}$ \\
& VUT-00003 & $12.5^{26}$ \\
Trichophyton asteroides & TIMM1189 & $>128^{15}$ \\
\hline Trichophyton rubrum & EP594 & $>128^{15}$ \\
\hline${ }^{a} \mathrm{MIC}_{80},{ }^{\mathrm{b}} \mathrm{MIC}_{50}$ & EP596 &
\end{tabular}

Odom at al. revealed, that in vitro FK506 was toxic to Cryptococcus neoformans at $37^{\circ} \mathrm{C}$, but not at $24^{\circ} \mathrm{C}$, because at the higher temperature growth and virulence were dependent on the protein phosphatase calcineurin. ${ }^{21}$ It was found, that tacrolimus inhibited CDR1 and CaMDR1 genes in C. albicans, which are thought to play a role in the antifungal resistance to azole derivatives. ${ }^{8}$ Along with the high level of stress that was induced by an influx $\mathrm{Ca}^{2+}$ and $\mathrm{Na}^{+}$the membrane distortion caused by the azole interference of the ergosterol metabolism gave rise to an enhanced intracellular FK506 concentration. ${ }^{9,27}$ In vitro studies with fluconazole-resistant $C$. glabrata isolates revealed a distinct synergistic effect when FK506 was combined with ketoconazole (77\%), itraconazole (73\%), voriconazole $(63 \%)$ and fluconazole $(60 \%) .{ }^{28}$ It has also been shown that tacrolimus dramatically induced $\mathrm{Ca}^{2+}$ uptake in C. glabrata cells in the presence of fluconazole ${ }^{29}$ or terbinafine and fenpropimorph. ${ }^{17}$ The addition of FK506 or the disruption of calcineurin gene CMP2 specifically reversed the $\beta$-1,3-glucan synthase Fks2-mediated resistance of C. glabrata to echinocandin ${ }^{30}$ as well as to posaconazole in C. albicans. ${ }^{16} \mathrm{Li}$ et al. ${ }^{19}$ mentioned the decrease in ERG11 and SNQ2 gene expression levels and the inhibition of fluconazole efflux by FK506 in Candida glabrata. Poeta et al..$^{20}$ demonstrated that it exhibits marked synergistic activity with the $\mathrm{H}^{+}$ATPase inhibitor bafilomycin $A_{1}$ and pneumocandin MK-0991/caspofungin acetate in C. neoformans cells. Steinbach et al. ${ }^{12}$ confirmed that FK506 and cyclosporin exhibit an inherent activity against Aspergillus fumigatus, generally delaying filamentation and producing smaller hyphae. Borba-Santos ${ }^{24} \mathrm{ob}-$ served an increase of itraconazole and fluconazole efficiency when applied in combination with FK506 in therapy regime for sporotrichosis, which is caused by pathogenic fungi Sporonthrix brasiliensis or S. schenckii. Ozawa et al. ${ }^{26}$ also revealed synergistic activity of tacrolimus with itraconazole against Trichophyton mentagrophytes. In contrast FK506 showed no high activity against Trichosporon asahii strains (MIC $>64.0 \mu \mathrm{g} / \mathrm{mL}$ ). ${ }^{25}$ However, a larger synergistic interaction was observed by the combinations FK506 + amphotericin B (96.67\%) and FK506 + caspofungin (73.33\%) against fluconazole-susceptible isolates of Trichosporon asahii. The activity of
FK506 in combination with azole antifungals against Malassezia species was investigated too. ${ }^{15,22}$

Also FK506 was thoroughly tested against fungal biofilms of $A$. fumigatus $^{14}$ and 60 selected clinical fungal isolates: ${ }^{13}$ A. flavus, A. terreus, A. ustus, A. niger, A. versicolor, Purpureocillium lilacinus, Paecilomyces variotii, Scopulariopsis spp., Rhizopus spp., Mucor spp., Rhizomucor spp., Lichtheimia spp., Cunninghamella spp., Fusarium spp., Scedosporium apiospermum and S. prolificans. Besides FK506 was reported to effect growth of Paecilomyces variotii, ${ }^{13}$ Cryptococcus neoformans, ${ }^{21}$ Neurospora crassa $a^{31}$ and Coccidioides immitis. ${ }^{32}$

\section{2. Antifungal Studies}

Considering the above-mentioned data, we decided to investigate antifungal activity of tacrolimus in concentrations of $1,0.05$ and $0.001 \mu \mathrm{g} / \mathrm{mL}$ against not studied before ten phytopathogenic fungi and three Phytophthora oomycetes: A. alternata, F. graminearum, B. cinerea, C. higginsianum, F. equiseti, F. fujikuroi, F. oxysporum, $P$. digitatum, V. lecanii, $M$. indicus, $P$. infestans $\mathrm{p}-4, \mathrm{GC}-1$ and $\mathrm{p}-3$. (Table 2). And also A. niger, that to our knowledge was the only one fungus treated earlier with FK506 (Table 1). ${ }^{13}$

So, it was found that at $1 \mu \mathrm{g} / \mathrm{mL}$ all fungi were susceptible to FK506, except $M$. indicus. A near complete inhibition of $99.0 \%$ was detected with $B$. cinerea. Whereas lowest effect $(21.1 \%)$ was observed with $V$. lecanii. Moreover, FK506 was always more active against any strain than the strong antifungal reference cyproconazole (2-(4-chlorphenyl)-3-cyclopropyl-1-(1H-1,2,4-triazol-1-yl)butan-2$\mathrm{ol})^{33}$ in the same concentration. And the results against the different strains of the same specie had the similar inhibition zones when treated with $1 \mu \mathrm{g} / \mathrm{mL}$ of tacrolimus.

Lowering the concentration to $0.05 \mu \mathrm{g} / \mathrm{mL}$ still conferred an inhibition of all strains. A. alternata, F. graminearum, $B$. cinerea, $C$. higginsianum and $A$. niger were the most sensitive ones and were effected more than $70 \%$.

Even at a 1000 times lower concentration $(0.001 \mu \mathrm{g} /$ $\mathrm{mL}$ ) moderate effects were still observed against $F$. graminearum (41.0\%), A. alternata (36.1\%), C. higginsianum (27.1\%), P. infestans p-4 (23.7\%) and A. niger (15.9\%), showing high efficiency of FK506 antifungal activity. 


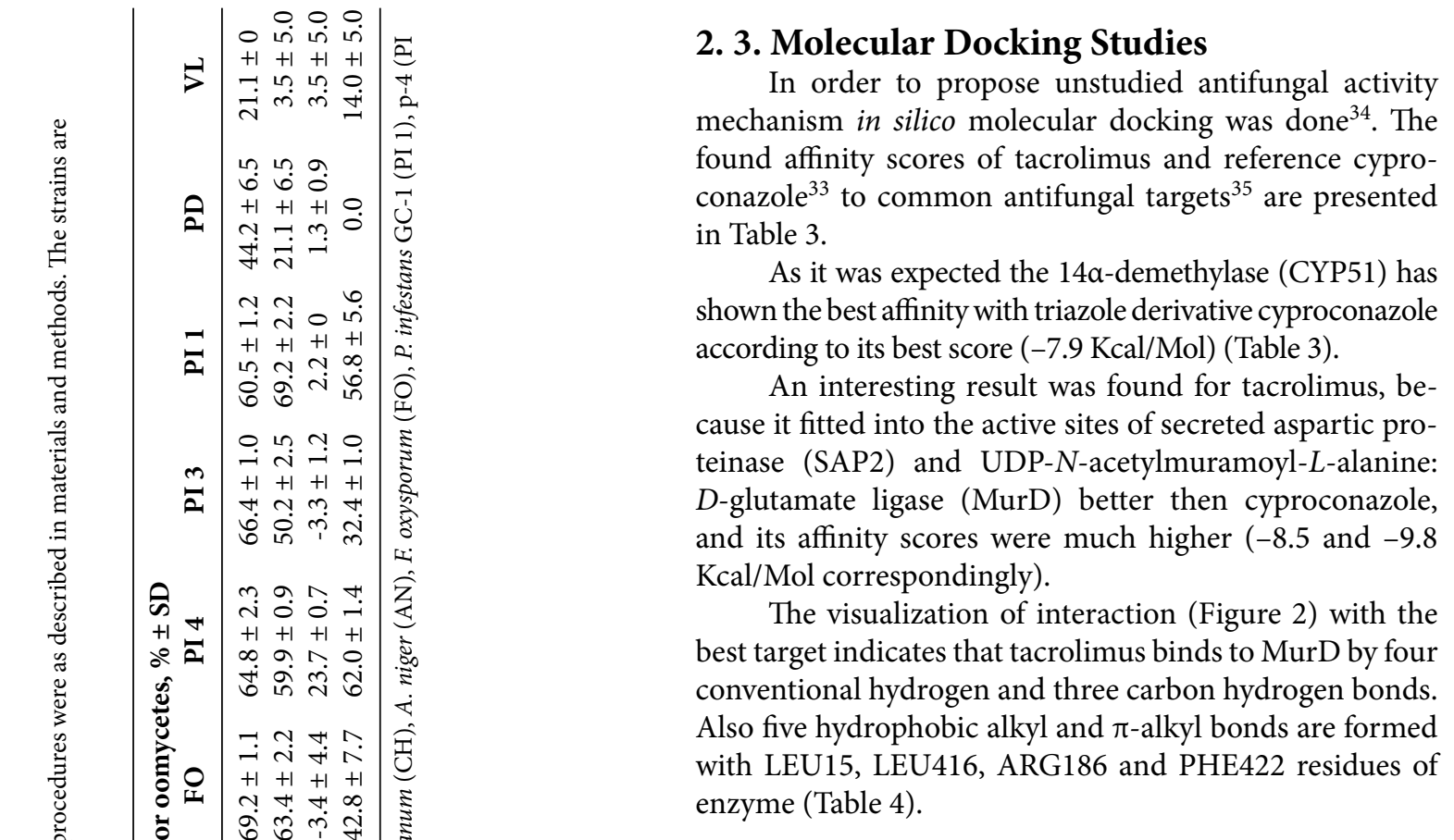

\section{Experimental}

The mycelial growth rate assay was used for antifungal studies. ${ }^{36}$ Strains of filamentous fungi were obtained from the following sources: Aspergillus niger DSM 246, Altenaria alternata DSM 1102, Fusarium equiseti DSM 21725, F. graminearum DSM 1095, F. fujikuroi DSM 893, Verticillium lecanii, Penicillium digitatum DSM 2731 from DSMZ (Braunschweig, Germany); Fusarium oxysporum 39/1201 St. 9336 and Botrytis cinerea from the Technische Universität Berlin (Germany); Colletotrichum higginsianum MAFF 305635, originally isolated in Japan, via the Department of Biology, Friedrich-Alexander-Universität (Erlangen, Germany); Phytophthora infestans GL-1 01/14 wild strain, p-3 (4/91; R+) and p-4 (4/91; R-) strains were kindly donated by Julius Kühn-Institut (Quedlinburg, Germany). Potato Dextrose Agar (PDA) were purchased from C. Roth (Karlsruhe, Germany). Cyproconazole (99\%) was obtained from (Sigma Aldrich, Germany). Tacrolimus (99\%) was purchased from Huaian Ruanke Trade, Ltd. (Huaian, China). Strains were cultivated on PDA for 6 $\mathrm{d}$ at $25{ }^{\circ} \mathrm{C}$. Spores from each strain were gently harvested with a sterile glass rod from plate surfaces with deionized water. Spore concentration numbers in suspension were determined microscopically and adjusted to $7.5^{\star} 10^{6}$ spores $/ \mathrm{mL}$. The clear stock solutions of $1 \mathrm{mg} / \mathrm{mL}$ were made of $0.01 \mathrm{~g}$ of cyproconazole and tacrolimus in $10 \mathrm{~mL}$ of deionized sterile water as solvent. $10 \mathrm{~mL}$ of these stock solutions were mixed in situ into $99 \mathrm{~mL}$ of PDA prior to solidification to obtain a final concentration of $1 \mu \mathrm{g} / \mathrm{mL}$. Additionally, from the same stock solution PDA solutions with final concentration of 0.05 and $0.001 \mu \mathrm{g} / \mathrm{mL}$ were made appropriately. $9 \mathrm{~mL}$ of each mixture were poured 
Table 3. Affinity to binding sites

The calculated affinity of substances to binding sites of sterol 14a-demethylase (CYP51) 5TZ1, $N$-myristoyltransferase (NMT) $1 \mathrm{IYL}$, secreted aspartic proteinase (SAP2) $1 \mathrm{EAG}$, UDP- $N$-acetylmuramoyl- $L$-alanine: $D$-glutamate ligase (MurD) $1 \mathrm{UAG}$, topoisomerase II (Topo II) 1Q1D, and $L$-glutamine: $D$-fructose-6-phosphate amidotransferase (GlcN-6-P) 1XFF.

\begin{tabular}{lcccccc}
\hline Substance & \multicolumn{2}{c}{ Candida albicans } & Kcal/Mol & Escherichia \\
& & & coli & $\begin{array}{c}\text { Sacchromyces } \\
\text { cerevisiae }\end{array}$ & $\begin{array}{c}\text { Escherichia } \\
\text { coli }\end{array}$ \\
\hline & $\mathbf{5 T Z 1}$ & $\mathbf{1 I Y L}$ & $\mathbf{1 E A G}$ & $\mathbf{1 U A G}$ & $\mathbf{1 Q 1 D}$ & $\mathbf{1 X F F}$ \\
Cyproconazole & -7.9 & -7.8 & -6.3 & -6.9 & -6.1 & -5.5 \\
Tacrolimus & -6.0 & -6.7 & -8.5 & -9.8 & -6.1 & -5.4 \\
\hline
\end{tabular}

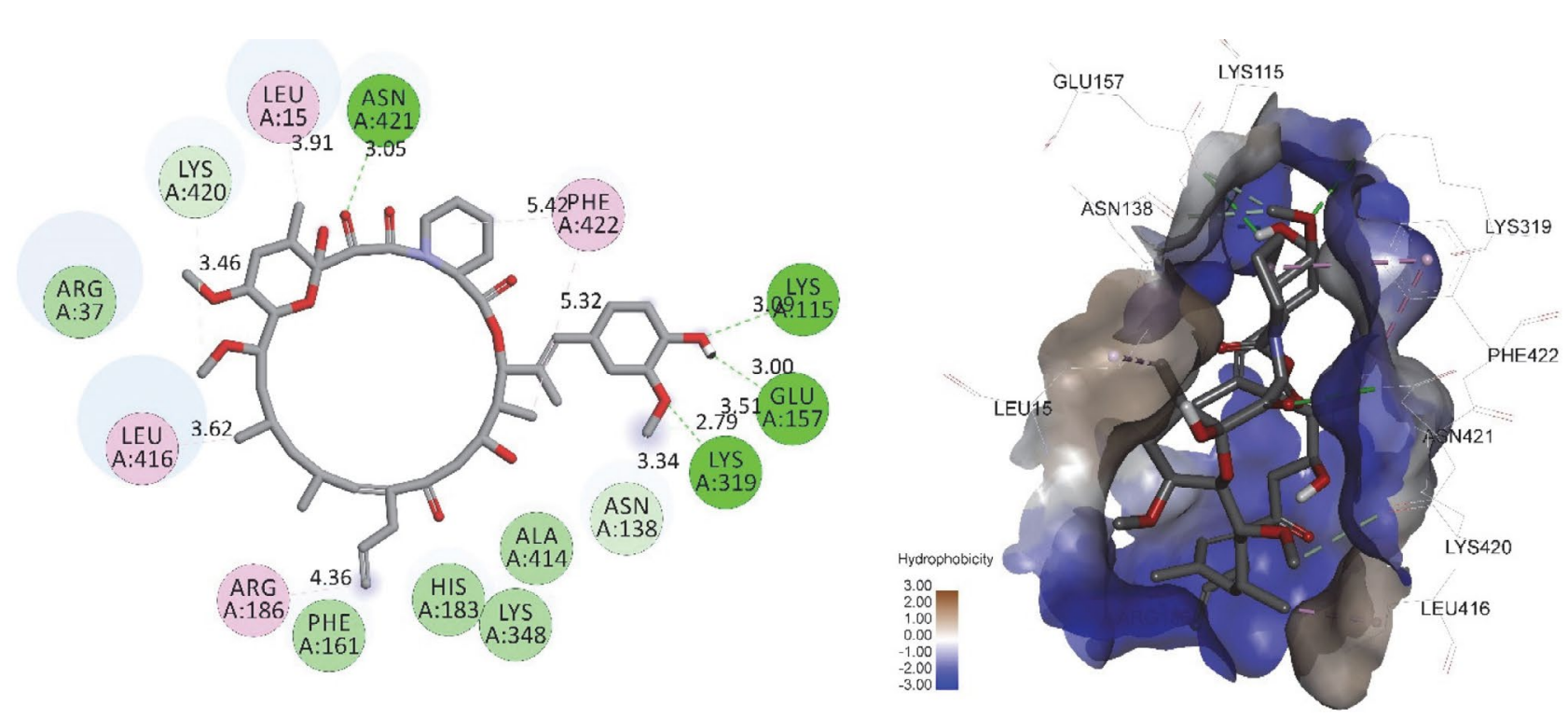

Figure 2. Visual representation (2D (left) and 3D (right)) of the tacrolimus showing bonds formation and position in the active site of UDP- $N$-acetylmuramoyl- $L$-alanine: $D$-glutamate ligase (MurD) 1 UAG. Pale green - van der Waals interaction, green - classical conventional hydrogen bond, light green - non classical carbon hydrogen bond, pink - hydrophobic alkyl and $\pi$-alkyl bonds.

Table 4. The list of in silico calculated bonds formed between tacrolimus and UDP-N-acetylmuramoyl-L-alanine: D-glutamate ligase (MurD) active site

\begin{tabular}{lccc}
\hline Name & Distance, & Category & Type \\
\hline A:LYS115:NZ - :UNL1:O & 3.09159 & Hydrogen & Conventional \\
A:LYS319:NZ - :UNL1:O & 2.78738 & Hydrogen & Conventional \\
A:ASN421:ND2 - :UNL1:O & 3.0506 & Hydrogen & Conventional \\
:UNL1:H - A:GLU157:OE2 & 2.99646 & Hydrogen & Conventional \\
:UNL1:C - A:LYS420:O & 3.45662 & Hydrogen & Carbon \\
:UNL1:C - A:ASN138:O & 3.33652 & Hydrogen & Carbon \\
:UNL1:C - A:GLU157:OE2 & 3.51104 & Hydrogen & Carbon \\
:UNL1:C - A:LEU15 & 3.90689 & Hydrophobic & Alkyl \\
:UNL1:C - A:LEU416 & 3.6241 & Hydrophobic & Alkyl \\
:UNL1:C - A:ARG186 & 4.36225 & Hydrophobic & Alkyl \\
A:PHE422 - :UNL1 & 5.42448 & Hydrophobic & $\pi$-Alkyl \\
A:PHE422 - :UNL1:C & 5.32047 & Hydrophobic & $\pi$-Alkyl \\
\hline
\end{tabular}

into $6 \mathrm{~cm}$ diameter petri dishes. A central hole (diameter: $2.5 \mathrm{~mm}$ ) was cut out and inoculated with $6.5 \mu \mathrm{L}$ spore suspension. Plates were incubated at $25^{\circ} \mathrm{C}\left(+/-1^{\circ} \mathrm{C}\right)$ for $6 \mathrm{~d}$. Control plates containing only PDA and DMSO were prepared in the same way. Inhibitory effects (I\%) were deter- mined by analyzing growth zone diameters and calculated as described $\left.{ }^{36}: \mathrm{I} \%=[(\mathrm{C}-\mathrm{T}) /(\mathrm{C}-2.5 \mathrm{~mm})]\right)^{\star} 100$, where $\mathrm{C}$ $(\mathrm{mm})$ represents the growth zone of control PDA, and T $(\mathrm{mm})$ the average growth zone in presence of tacrolimus. All growth experiments were carried out in triplicate. 
Means and standard deviations were calculated with software "Excel 2016" (Microsoft, USA). The strong antifungal agent was used as positive control.

Molecular docking. Macromolecular data of crystal structures were downloaded from the Protein Data Bank (PDB): ${ }^{37}$ sterol 14a-demethylase (CYP51) 5TZ1, topoisomerase II (Topo II) 1Q1D, L-glutamine: D-fructose-6-phosphate amidotransferase (GlcN-6-P) 1XFF, secreted aspartic proteinase (SAP2) 1EAG, $N$-myristoyltransferase (NMT) 1IYL, and UDP- $N$-acetylmuramoyl-L-alanine: D-glutamate ligase (MurD) 1UAG; taken from Candida albicans (CYP51, NMT, SAP2), Escherichia coli (MurD, GlcN-6-P) and Sacchromyces cerevisiae (Topo II). ${ }^{35}$ As reference cyproconazole (2-(4-chlorphenyl)3-cyclopropyl-1-(1H-1,2,4-triazol-1-yl)butan-2-ol) was chosen. $^{33}$

Ligand preparation. Substances were drawn using MarvinSketch 6.3.0 and were saved in mol format. They were optimized by program Chem3D using molecular dynamics MM2 algorithm and saved as pdb-files. Molecular mechanics was used to produce more realistic geometry values for the majority of organic molecules owing to the fact of being highly parameterized. By using AutoDockTools-1.5.6 pdb-files were converted to PDBQT, and number of active torsions was set as default.

Protein preparation. Discovery Studio 4.0 was used to delete water molecules and ligand from crystal structures. The proteins were saved as pdb-files. In AutoDockTools-1.5.6 polar hydrogens were added and saved as PDBQT. The Grid boxes were set as following: $5 T Z 1$ center_x $=70.728$, center $\_y=65.553$, center $\_z=3.865$, size $\_x=35$, size_y $=35$, size $\_z=35 ; 1 Q 1 D$ center_x $=28.5$, center_y $=$ 34.4 , center $\_z=32.7$, size $\_x=30$, size $\_y=30$, size $\_z=30$; $1 X F F$ center_x $=5$, center_y $=28$, center_ $z=26$, size_ $x=$ 30 , size $\_y=30$, size_z $=30 ; 1$ UAG center_x $=47$, center_y $=-1.5$, center $\_z=15$, size $\_x=30$, size $\_y=30$, size $\_z=30$, 1IYL center_x $=31$, center_y $=74.5$, center_z $=57$, size_x $=30$, size $\_y=30$, size $\_z=30,1 E A G$ center $\_x=42$, center_y $=26$, center_ $z=11$, size_x $=30$, size $\_y=30$, size $\_z=$ 30. Vina was used to carry out docking. For visualization Discovery Studio Visualizer v17.2.0.16349 was used.

\section{Conclusion}

Considering a substantial role of FK506 in crop protection due to its distinct activity against phytopathogenic fungi, the availability in bulk quantities at affordable costs have to be taken into account. ${ }^{38}$ For the development of a formulation for agricultural usage purity standards may be much less demanding than for immunosuppressant manufacturing. Furthermore, quantities necessary of tacrolimus may be reduced if advantages of synergistic effects in blends with conventional antifungal agrochemicals (e.g. triazoles) can be generated as it is already described for medical care of patients infected with C. albicans. ${ }^{8}$ Investi- gations to further explore the potential benefits of FK506 in agriculture must be accompanied by studies covering emergence of resistance, toxicity and environmental friendliness of this compound.

\section{Acknowledgements}

Authors gratefully acknowledge German Federal Ministry of Education and Research (Grant: FKZ 03FH025IX4) for financial support of this work; Federal Research Centre for Cultivated Plants (Quedlinburg, Germany) for presenting the strain Phytophthora infestans; Department of Biology, Friedrich Alexander University, Erlangen, Nürnberg, Germany for the strain Colletotricum higginsianum.

\section{References}

1. A. H. Fairlamb, N. A. Gow, K. R. Matthews, A. P. Waters. Nat. Microbiol. 2016, 1, 1-14. DOI:10.1038/nmicrobiol.2016.92

2. A. Paugam, J. Dupouy-Camet, P. Blanche, J. P. Gangneux, C. Tourte-Schaefer, D. Sicard. Clin. Infect. Dis. 1994, 19, 975976. DOI:10.1093/clinids/19.5.975-a

3. M. L. Cameron, W. A. Schell, S. Bruch, J. Bartlett, H. A. Waskin, J. R. Perfect. Antimicrob. Agents Chemother. 1993, 37, 2449-2453. DOI:10.1128/AAC.37.11.2449

4. P. R. Juvvadi, F. Lamoth, W. J. Steinbach. Fungal Biol. Rev. 2014, 28 (2-3), 56-69. DOI:10.1016/j.fbr.2014.02.004

5. H. Tanaka, A. Kuroda, H. Marusawa, H. Hatanaka, T. Kino, T. Goto, M. Hashimoto, T. Taga. J. Am. Chem. Soc. 1987, 109 (16), 5031-5033. DOI:10.1021/ja00250a050

6. TOXNET - U.S. National Library of Medicine TOXICOLOGY DATA NETWORK https://toxnet.nlm.nih.gov/cgi-bin/ sis/search2/r?dbs+hsdb:@term+@rn+@rel+104987-11-3 (accessed: August 17, 2018).

7. R. J. Sr. Lewis (Ed.): Sax's Dangerous Properties of Industrial Materials. $11^{\text {th }}$ Edition. Wiley-Interscience, Wiley \& Sons, Inc. Hoboken, NJ, 2004, p. 3344.

8. S. Maesaki, P. Marichal, M. A. Hossain, D. Sanglard, H. ven Bossche, S. J. Kohno. Antimicrob. Chemother. 1998, 42 (6), 747-753. DOI:10.1093/jac/42.6.747

9. P. Uppuluri, J. Nett, J. Heitman, D. Andes. Antimicrob. Agents Chemother. 2008, 52 (3), 1127-1132.

DOI:10.1128/AAC.01397-07

10. J. Schumacher, I. F. de Larrinoa, B. Tudzynski. Eukaryot. Cell 2008, 7 (4), 584-601. DOI:10.1128/EC.00426-07

11. J. H. Choi, Y. Kim, Y. H. Lee. J. Microbiol. Biotechnol. 2009, 19 (1), 11-6.

12. W. J. Steinbach, W. A. Schell, J. R. Blankenship, C. Onyewu, J. Heitman, J. R. Perfect. Antimicrob. Agents Chemother. 2004, 48 (5), 1664-1669. DOI:10.1128/AAC.48.5.1664-1669.2004

13. F. Lamoth, B. D. Alexer, P. R. Juvvadi, W. J. Steinbach. J. Antimicrob. Chemother. 2014, 70 (5), 1408-1411.

DOI:10.1093/jac/dku549 
14. L. Gao, Y. Sun. Antimicrob. Agents Chemother. 2015, 59 (11), 7097-7099. DOI:10.1128/AAC.01510-15

15. H. Nakagawa, T. Etoh, Y. Yokota, F. Ikeda, K. Hatano, N. Teratani, K. Shimomura. Clin. Drug Invest. 1996, 12 (5), 244-250. DOI:10.2165/00044011-199612050-00003

16. Y. L. Chen, V. N. Lehman, A. F. Averette, J. R. Perfect, J. Heitman. PLoS One 2013, 8 (3), e57672.

DOI:10.1371/journal.pone.0057672

17. C. Onyewu, J. R. Blankenship, M. Del Poeta, J. Heitman. Antimicrob. Agents Chemother. 2003, 47 (3), 956.

DOI:10.1128/AAC.47.3.956-964.2003

18. S. Sun, Y. Li, Q. Guo, C. Shi, J. Yu, L. Ma. Antimicrob Agents Chemother. 2008, 52 (2), 409-417.

DOI:10.1128/AAC.01070-07

19. H. Li, Z. Chen, C. Zhang, Y. Gao, X. Zhang, S. Sun. J. Med. Microbiol. 2015, 64 (1), 44-52.

DOI:10.1099/jmm.0.081760-0

20. M. Del Poeta, M. C. Cruz, M. E. Cardenas, J. R. Perfect, J. Heitman. Antimicrob. Agents Chemother. 2000, 44 (3), 739746. DOI:10.1128/AAC.44.3.739-746.2000

21. A. Odom, M. Del Poeta, J. Perfect, J. Heitman. Antimicrob. Agents Chemother. 1997, 41 (1), 156-161.

DOI:10.1128/AAC.41.1.156

22. T. Sugita, M. Tajima, T. Ito, M. Saito, R. Tsuboi, A. Nishikawa. J. Clin. Microbiol. 2005, 43 (6), 2824-2829.

DOI:10.1128/JCM.43.6.2824-2829.2005

23. L. Brizuela, G. Chrebet, K. A. Bostian, S. A. Parent, Mol. Cell. Biol. 1991, 11 (9), 4616-4626. DOI:10.1128/MCB.11.9.4616

24. L. P. Borba-Santos, L. F. Reis de Sá, J. A. Ramos, A. M. Rodrigues, Z. P. de Camargo, S. Rozental, A. Ferreira-Pereira. Front. Microbiol. 2017, 8, 1-9. DOI:10.3389/fmicb.2017.01759

25. T. F. Kubiça, L. B. Denardi, M. I. Azevedo, V. Oliveira, L. C. Severo, J. M. Santurio, S. H. Alves. Brazilian J. Infect. Dis. 2016, 20 (6), 539-545. DOI:10.1016/j.bjid.2016.08.008
26. H. Ozawa, K. Okabayashi, R. Kano, S. Watanabe, A. Hasegawa. J.Vet.Med.Sci. 2005, 67, 629-630. DOI:10.1292/jvms.67.629

27. J. R. Blankenship, J. Heitman. Infect. Immun. 2005, 73, 57675774. DOI:10.1128/IAI.73.9.5767-5774.2005

28. L. B. Denardi, D. A. N. Mario, É. S. Loreto, J. M. Santurio, S. H. Alves. Brazilian J. Microbiol. 2015, 46 (1), 125-129. DOI:10.1590/S1517-838246120120442

29. R. Kaur, I. Castan o B. P. Cormack. Antimicrob. Agents Chemother. 2004, 48, 1600-1613. DOI:10.1128/AAC.48.5.1600-1613.2004

30. S. K. Katiyar, A. Alastruey-Izquierdo, K. R. Healey, M. E. Johnson, D. S. Perlin, T. D. Edlind. Antimicrob. Agents Chemother. 2012, 56, 6304-6309. DOI:10.1128/AAC.00813-12

31. M. Tropschug, I. B. Barthelmess, W. Neupert. Nature 1989, 342, 953-955. DOI:10.1038/342953a0

32. Kirkl, T. N. J. Fierer. Antimicrob. Agents Chemother. 1983, 24, 921-924. DOI:10.1128/AAC.24.6.921

33. PPDB: Pesticide Properties DataBase. Cyproconazol. http:// sitem.herts.ac.uk/aeru/ppdb/en/Reports/198.htm (accessed: August 21, 2019).

34. J. Alvarez, B. Shoichet, PART V: Docking Strategies and Algorithms, Virtual Screening in Drug Discovery. CRC Press, Taylor \& Francis: Boca Raton, FL, 2005, pp. 301-348. DOI:10.1201/9781420028775

35. A.Siwek,P.Staczek,A.Strzelczyk,J.Stefanska.Lett.Drug.Design. Discov. 2013, 10, 2-10. DOI:10.2174/157018013804142393

36. R. Tang, L. Jin, C. Mou, J. Yin, S. Bai, D. Hu, J. Wu, S. Yang, B. Song. Chem. Cent. J. 2013, 7, 1-8.

DOI: $10.1186 / 1752-153 X-7-30$

37. Worldwide Protein Data Bank. http://www.pdb.org (accessed: April 12, 2018).

38. C. Barreiro, M. Martínez-Castro. Appl. Microbiol. Biotechnol. 2014, 98 (2): 497-507. DOI:10.1007/s00253-013-5362-3

\section{Povzetek}

Takrolimus (FK506) je imunosupresivno zdravilo, ki se pogosto uporablja za preprečevanje zavrnitve organov pri bolnikih s presaditvijo. Ima močan vpliv na celični stresni odziv $\mathrm{z}$ vmešavanjem v signalno pot kalmodulin-kalcinevrin. $\mathrm{V}$ tem kontekstu je FK506 postal tudi dragoceno protiglivično zdravilo v zdravstveni negi. Tu je in vitro prikazano, da ima takrolimus močan učinek zaviranja rasti proti 11 glivam in 3 oomicetom kmetijskega pomena. Pomen te ugotovitve je obravnavan v zvezi z zaščito pridelkov.

Except when otherwise noted, articles in this journal are published under the terms and conditions of the Creative Commons Attribution 4.0 International License 